\title{
Assessment of Lower Urinary Tract Symptoms and Sexual Function in Women with Metabolic Syndrome
}

\section{Metabolik Sendromlu Kadınlarda Alt Üriner Sistem Semptomları ve Cinsel Fonksiyonun Değerlendirilmesi}

\author{
Serkan Borazan1, Gökhan Temeltaş1, Oktay Üçer1, Zeliha Hekimsoy2, Emel Şenol2 \\ 'Celal Bayar University Faculty of Medicine, Department of Urology, Manisa, Turkey \\ 2 Celal Bayar University Faculty of Medicine, Department of Endocrinology and Metabolism, Manisa, Turkey
}

\begin{abstract}
What's known on the subject? and What does the study add?
Although there are a lot of studies to examine the association LUTS and sexual dysfunction with MetS in men, there are limited number studies to evaluate this association in women. We found that although the prevalence of LUTS and sexual dysfunction in women with MetS was higher than women without MetS, LUTS in these women with MetS did not significantly affect quality of life.
\end{abstract}

\section{ABSTRACT}

\section{Objective}

To assess lower urinary tract symptoms and sexual function in premenopausal women with metabolic syndrome (MetS).

\section{Materials and Methods}

A total of 34 premenopausal patients over 18 years of age with MetS and who were admitted to our endocrinology clinic between September 2013 and April 2014 were included. Control group was consisted of 30 healthy controls chosen from the staff of the hospital. The sexual function, lower urinary tract symptoms and quality of life of the participants were evaluated by using Index of Female Sexual Function (IFSF), Urogenital Distress Inventory (UDI-6), and Incontinence Impact Questionnaire (IIQ-7), respectively. The scores of the patients were statistically compared with those of controls.

\section{Results}

The mean ages of the patient and control groups were $40.50 \pm 5.12$ years and $38.17 \pm 2.12$ years, respectively $(p=0.09)$. The mean IFSF-total and all of the IFSF sub scales (except pain) in the patient group were significantly lower than those of the control group. The mean UDI-6 score of the patients was significantly higher than the controls $(p=0.001)$. The mean IIQ-7 scores of the patients was higher than controls, however this increase was not statistically significant ( $p=0.11)$.

\section{Conclusion}

These findings showed that MetS affected adversely the sexual function of premenopausal women due to the fact that IFSF scores were found to be lower in women with MetS as compared to healthy controls. Moreover, IFSF score under the threshold values in patients showed that patients with MetS had sexual function disorder. These lower urinary tract symptoms in the patients with MetS did not affect the quality of life although the severity of lower urinary tract symptoms of patients with MetS was significantly worse than that in control group.

\section{Key Words}

Metabolic syndrome, LUTS, female sexual function, IFSF, UDI-6, IIQ-7

\section{ÖZET}

Amaç

Çalışmamızın amacı metabolik sendromlu (MetS) premenapozal kadınlarda cinsel fonksiyon ve alt üriner sistem semptomlarının değerlendirilmesi.

Gereç ve Yöntem

Eylül 2013-Nisan 2014 tarihleri arasında Endokrinoloji polikliniğine başvuran 18 yaş üstü, menopoza girmemiş, MetS olan kadın hastalar çalışmaya dahil edildi ( $n=34)$. Kontrol grubu hastane çalışanı kadınlardan oluştu $(n=30)$. Tüm hastalara IFSF (Kadın Cinsel Fonksiyon İndeksi), UDI-6 (Ürogenital Rahatsızlık Envanteri), IIQ-7 (Inkontinans Etki Formu) formları dolduruldu. Hasta ve kontrol grubu bu üç formun skorları açısından istatistiksel olarak karşılaştıııldı.

\section{Bulgular}

Çalışmamızın hasta grubunun ortalama yaşı 40,50 $\pm 5,12$ yıl, kontrol grubunun ise $38,17 \pm 2,12$ yll şeklinde bulundu $(p=0,09)$. MetS'li kadınlarda IFSF toplam ve tüm alt grup skorları (ağrı dışında) kontrol grubuyla karşılaştırıldığında anlamlı olarak düşüktü. UDI-6 skorları hasta grubunda anlamlı olarak daha yüksek bulundu $(p=0,001)$. IIQ-7 skorları ise hasta grubunda daha yüksekti ancak, bu istatistiksel olarak anlamsızdı $(p=0,11)$.

\section{Sonuç}

IFSF skorlarının MetS'li kadınlarda normal sağlıklı kadınlara oranla daha düşük bulunması bu hastalığa bağlı olarak cinsel fonksiyonun etkilendiğini göstermektedir. Hatta hastalardaki IFSF skorunun, eşik değerin altında kalması MetS'li kadınlarda cinsel fonksiyon bozukluğunun olduğunu da göstermektedir. MetS'li kadınlarda alt üriner sistem semptomları şiddeti kontrol grubundan anlamlı olarak daha kötü olmasına rağmen, bu semptomların hastalarda yaşam kalitesini etkilemediği görüldü.

Anahtar Kelimeler

Metabolik sendrom, AÜSS, kadın cinsel fonksiyonu, FSFI, UDI-6, II0-7

\section{Correspondence}

Serkan Borazan MD, Celal Bayar University Faculty of Medicine, Department of Urology, Manisa, Turkey

Phone: +90 2323244543 E-mail: srkn.brz@hotmail.com Received: 22.01.2015 Accepted: 27.01.2015 


\section{Introduction}

The metabolic syndrome (MetS) consists of visceral adiposity, hypertension, glucose intolerance, and dyslipidemia (elevated triglycerides and decreased HDL-cholesterol concentrations). MetS predicts type 2 diabetes, cardiovascular disease, and all-cause mortality in non-diabetic individuals and has become a major health challenge worldwide in adult populations (1). Metabolic syndrome prevalence was found as 36.6\% (males: $30.3 \%$, females: $41.8 \%$ ) according to Adult Treatment Panel III (ATP III) and 44.0\% (males: 37.0\%, females: 49.8\%) according to International Diabetes Federation (IDF) in Turkey. The prevalence of MetS increases with age in men and women (2).

Several factors causing or affecting lower urinary tract symptoms (LUTS) have recently been indicated: age; race; micturitional habit; and lifestyle factors, such as alcohol consumption, smoking, excessive fluid intake and metabolic syndrome, as well as pathological conditions of detrusor activity and/or bladder outlet obstruction (3). Although there are a lot of studies to examine the association LUTS with MetS in men, there are limited number studies to evaluate this association in women.

In our country, there are limited data about epidemiology and prevalence of female sexual dysfunction (FSD) because there is no multicentric study to indicate the prevalence of FSD. Çayan et al. reported that based on total sexual function score, 84 (46.9\%) out of 179 women had sexual dysfunction. They also noticed the prevalence of FSD for each domain increased with age (4). Previously studies indicated that sexual dysfunction had direct relationship with MetS in men (5). However there are limited data about this relationship in women in literature.

Our study aimed to compare the sexual function (by using Index of Female Sexual Function (IFSF)) and LUTS (by using Urogenital Distress Inventory (UDI-6) and Incontinence Impact Questionnaire (IIQ-7)) in pre-menopausal women who had MetS with healthy controls.

\section{Materials and Methods}

The study comprised 34 consecutive premenopausal women with MetS who had attended the endocrinology and metabolism clinic as outpatients between September 2013 and April 2014 and 30 healthy controls. In all participants, height and weight were recorded, and body mass index was calculated (BMI, body weight in $\mathrm{kg} /($ height in meters)2). Biochemical investigations included, fasting blood sugar, post prandial blood sugar, $\mathrm{HbA} 1 \mathrm{c}$, blood lipid tests and liver function tests. The patients' blood pressures were also measured. Controls $(n=30)$ were chosen from among healthy hospital staff who were the same age group as the patients. The exclusion criteria of this study were psychological disorders, malignancies, menopause and pregnancy. All participants filled out IFSF, UDI-6, IIQ-7. An informed consent form was obtained from all participants. The study protocol was approved by the Local Ethics Committee.

\section{Instruments}

IFSF was used to assess sexual function of the women in the patient and control groups. IFSF is used to assess the female sexual dysfunction. It is psychometrically sound, easy to administer and has demonstrated ability to discriminate between clinical and nonclinical populations. This test is derived from the adaptation of the
International Index of Erectile Function described by Rosen himself (6). The scale consists of 19 items divided into six subscales including sexual desire, sexual arousal, lubrication, orgasm, sexual satisfaction, and sexual pain with 2, 4, 4, 3, 3 and 3 items, respectively. The measure allows the calculation of specific indexes for each dimension as well a sexual function index (calculated through the sum of the specific dimensional indexes), with higher scores indicating greater levels of sexual functioning (desire: 1.2-6, arousal: 0-6, lubrication: 0-6, orgasm: 0-6, global satisfaction: 0.8-6, pain: 0-6, total: 2-36). Turkish version of the IFSF was validated by Aygin and Aslan (7).

The UDI-6 is a six item symptom inventory, specific to symptoms associated with lower urinary tract dysfunction, and combines information on irritative, stress and obstructive/discomfort symptoms. The IIQ-7 is a seven item life-impact assessment instrument specific to $\mathrm{UI}$, and covers separate domains of physical activity, travel, social/ relationships, and emotional health. Higher scores indicate more symptom distress (UDI-6), or more impact on daily life (IIQ-7). There are four response options per item ((0) "not at all"; (1) "slightly"; (2) "moderately"; (3) "greatly") for every question in the both forms.

\section{Results}

The mean of the patients and controls was $40.50 \pm 5.12$ and $38.17 \pm 2.12$, respectively $(p=0.09)$. Height, weight, BMI and biochemical data in the patients were given (Table 1). Systemic disease features of the patients were also given (Table 2). Compared the mean IFSF total and subscale scores of the patients with control group; all scores except pain were significantly lower in the patient group (Table 3). Although the mean UDI-6 score of the patients was significantly higher than the controls, there was no significant difference between IIQ-7 scores in the patient and control group (Table 3).

Table 1 . The height, body weight, body mass index and serum values of the patients

\begin{tabular}{|l|l|l|}
\hline & Mean \pm SD & $\begin{array}{l}\text { Minimum - } \\
\text { Maximum }\end{array}$ \\
\hline Height $(\mathrm{cm})$ & $158 \pm 4$ & $150-170$ \\
\hline Weight $(\mathrm{kg})$ & $97.60 \pm 14.49$ & $78-135$ \\
\hline Body Mass Index (kg/m²) & $38.86 \pm 5.32$ & $30,85-54,08$ \\
\hline Fasting blood glucose (mg/dl) & $119.06 \pm 39.88$ & $86-279$ \\
\hline Postprandial blood glucose (mg/dl) & $156.18 \pm 41.64$ & $108-240$ \\
\hline LDL (mg/dl) & $138.27 \pm 33.32$ & $75-225$ \\
\hline VLDL (mg/dl) & $90.43 \pm 95.98$ & $16-305$ \\
\hline TG (mg/dl) & $168.06 \pm 87.06$ & $78-400$ \\
\hline HbA1c (\%) & $6.67 \pm 2.32$ & $0,32-11,43$ \\
\hline AST (U/L) & $22.80 \pm 6.93$ & $10-37$ \\
\hline ALT (U/L) & $24.34 \pm 12.87$ & $9-58$ \\
\hline HDL (mg/dl) & $57.68 \pm 10.48$ & $36-81$ \\
\hline TA systolic (mmHg) & $136.55 \pm 7.20$ & $110-150$ \\
\hline TA diastolic (mmHg) & $85.17 \pm 5.74$ & $70-90$ \\
\hline
\end{tabular}


Table 2. Systemic disorder features of the patients $(n=34)$

\begin{tabular}{|l|l|l|}
\hline Systemic disorders & $(+)(\%)$ & $(-)(\%)$ \\
\hline Diabetes Mellitus & $26(76)$ & $8(24)$ \\
\hline Hypertension & $24(71)$ & $10(29)$ \\
\hline Hyperlipidemia & $20(59)$ & $14(41)$ \\
\hline
\end{tabular}

Table 3. Female sexual function index (IFSF), Urogenital distress inventory (UDi-6) and Incontinence impact questionnaire (IIO-7) scores in the patient and control group

\begin{tabular}{|l|l|l|l|}
\hline & $\begin{array}{l}\text { Patients group } \\
(\mathrm{n}=34) \\
\text { Mean } \pm \text { SD }\end{array}$ & $\begin{array}{l}\text { Control group } \\
(\mathrm{n}=30) \\
\text { Mean } \pm \text { SD }\end{array}$ & p value \\
\hline Age (years) & $40.50 \pm 5.12$ & $38.17 \pm 2.12$ & 0.09 \\
\hline IFSF-desire & $3.00 \pm 1.39$ & $4.23 \pm 0.83$ & $0.003^{*}$ \\
\hline IFSF-arousal & $2.31 \pm 1.07$ & $4.18 \pm 0.96$ & $0.000^{* *}$ \\
\hline IFSF-lubrication & $3.26 \pm 1.51$ & $4.51 \pm 0.97$ & $0.007^{*}$ \\
\hline IFSF-orgasm & $2.40 \pm 1.42$ & $4.25 \pm 1.00$ & $0.000^{* *}$ \\
\hline IFSF-satisfaction & $2.64 \pm 1.30$ & $4.51 \pm 0.99$ & $0.000^{* *}$ \\
\hline IFSF-pain & $3.75 \pm 1.74$ & $4.49 \pm 0.94$ & 0.12 \\
\hline IFSF-total & $17.38 \pm 7.50$ & $26.70 \pm 4.44$ & $0.000^{* *}$ \\
\hline UDi-6 & $6.27 \pm 3.90$ & $2.47 \pm 1.37$ & $0.001^{*}$ \\
\hline IIQ-7 & $6.38 \pm 5.65$ & $3.88 \pm 3.29$ & 0.11 \\
\hline
\end{tabular}

IFSF: Female Sexual Function Index, UDI-6: Urogenital Distress Inventory,

IIQ-7: Incontinence Impact Questionnaire,

${ }^{*} p<0,05,{ }^{* *} p<0,001$

\section{Discussion}

Female sexual dysfunction is a common and multidimensional disorder related to a broad variety of biological, psychological and interpersonal determinants (8). While old data reveal that up to $76 \%$ of women had some type of sexual dysfunction, more recent estimates indicate that $43 \%$ of women complain of at least one sexual problem (9). The most important risk factor for FSD is age. In a previous study, women aged 60-69 years had a 2.8-fold higher risk for desire disorders, a 5.1-fold increased risk for arousal disorders and a 3.7fold higher risk for orgasmic disorders compared to young controls. Our study has shown that women with the metabolic syndrome have an increased prevalence of sexual dysfunctions as compared with matched control women. We found that the IFSF mean scores of the patients and controls were 17.38 and 26.70, respectively $(p<0.001)$. Wiegel et al. (10) found an IFSF total score of 26.55 to be the optimal cut-off score for differentiating women with and without sexual dysfunction. Overall, the findings suggested that MetS may cause sexual dysfunction in premenopausal women. Esposito et al (9) evaluated the prevalence of FSD in 120 premenopausal women with MetS from their endocrinologic outpatient clinic and compared these data to a control group of 80 premenopausal women without MetS (matched for age and BMI). The patient group had a reduced
IFSF score (23.2 vs $30.1 ; p<0.001)$, a reduced satisfaction rate and significantly lower arousal, orgasm and lubrication scores. Similarly, our study data indicated that all components (except pain) of female sexual function in patients with MetS were worse than women without MetS. Ponholzer et al. (8) indicated that in premenopausal women, the MetS was an independent risk factor for impaired sexual desire $(p=0.03)$ with an age-adjusted odds ratio of $3.3(95 \%$ confidence interval: 1.5-7.3). However they found that there was no any difference the other components of female sexual function in premenopausal women with MetS. This difference between results of our and their studies may due to assess FSD with different forms. They used a form that had not validated German to evaluate FSD.

In a previous study, 36.7\% of women with type 2 diabetes were considered to have moderate to severe LUTS on careful questioning at the diabetic clinics. They also indicated that compared with the nonMetS group, the MetS group reported significantly higher storage and total symptom scores and a borderline increase in voiding symptom. When individual symptoms were compared, the average score of urgency, nocturia, and intermittency was significantly higher in the MetS group (11). In an other study, a total of 2371 men (mean age 46.1 years) and 731 women (mean age 53.9 years) were analyzed. According to their results, the MetS did not turn out to be significantly and independently involved in the genesis of LUTS in men or women (12). The results of the two studies are inconsistent. We compared LUTS in premenopausal women with and without Mets by using UDI6. The mean UDI-6 scores of the patients and controls were found to be $6.27 \pm 3.90$ and $2.47 \pm 1.37$, respectively $(p=0.001)$. We also evaluated the effect on quality of life of urinary incontinence and pelvic organ prolapse by using IIQ-7. Although the mean IIQ-7 score of the patients was found higher than the controls, this difference was not statistically significant ( $p=0.11$ ).

\section{Conclusion}

Our study indicated that the sexual function of premenopausal women with MetS affected adversely. These patients had female sexual dysfunction because the mean IFSF score of the patients was too lower than the threshold of IFSF. Although the prevalence of LUTS in women with MetS was higher than women without MetS, LUTS in these women with MetS did not significantly affect quality of life. Further studies should make hormone analysis in women with MetS to better assess FSD.

\section{Conflict of interest}

There are no conflicts of interest.

\section{References}

1. Ekelund $U$, Anderssen $S$, Andersen LB, Riddoch CJ, Sardinha LB, Luan J, Froberg $\mathrm{K}$, Brage $\mathrm{S}$. Prevalence and correlates of the metabolic syndrome in a population-based sample of European youth. Am J Clin Nutr 2009;89:90-96.

2. Gundogan K, Bayram F, Gedik V, Kaya A, Karaman A, Demir O, Sabuncu T, Kocer D, Coskun R. Metabolic syndrome prevalence according to ATP III and IDF criteria and related factors in Turkish adults. Arch Med Sci 2013;9:243-253.

3. Osuga $Y$, Okamura $K$, Ando F, Shimokata H. Prevalence of lower urinary tract symptoms in middle-aged and elderly Japanese. Geriatr Gerontol Int 2013;13:1010-1017. 
4. Cayan S, Akbay E, Bozlu M, Canpolat B, Acar D, Ulusoy E. The prevalence of female sexual dysfunction and potential risk factors that may impair sexual function in Turkish women. Urol Int 2004;72:52-57.

5. Amidu N, Owiredu WK2, Alidu H2, Sarpong C3, Gyasi-Sarpong CK4, Quaye L. Association between metabolic syndrome and sexual dysfunction among men with clinically diagnosed diabetes. Diabetol Metab Syndr 2013;5:42.

6. Rosen R, Brown C, Heiman J, Leiblum S, Meston C, Shabsigh R, Ferguson D, D'Agostino R Jr. The Female Sexual Function Index (FSFI): a multidimensional self-report instrument for the assessment of female sexual function. J Sex Marital Ther 2000;26:191-208.

7. Aygin D, Aslan F. The Turkish adaptation of the female sexual function index. Turkiye Klinikleri J Med Sci 2005;25:393-399.

8. Ponholzer A, Temml C, Rauchenwald M, Marszalek M, Madersbacher S. Is the metabolic syndrome a risk factor for female sexual dysfunction in sexually active women? Int J Impot Res 2008;20:100-104.
9. Esposito K, Ciotola M, Marfella R, Di Tommaso D, Cobellis L, Giugliano D. The metabolic syndrome: a cause of sexual dysfunction in women. Int J Impot Res 2005;17:224-226.

10. Wiegel $M$, Meston $C_{1}$ Rosen R. The female sexual function index (FSFI): cross-validation and development of clinical cutoff scores. J Sex Marital Ther 2005;31:1-20.

11. Tai HC, Chung SD, Ho CH, Tai TY, Yang WS, Tseng CH, Wu HP, Yu HJ. Metabolic syndrome components worsen lower urinary tract symptoms in women with type 2 diabetes. J Clin Endocrinol Metab 2010;95:11431150.

12. Temml C, Obermayr R, Marszalek $M$, Rauchenwald M, Madersbacher $S$, Ponholzer A. Are lower urinary tract symptoms influenced by metabolic syndrome? Urology 2009;73:544-548. 